\title{
Peningkatan Kemampuan Melaksanakan Inovasi Pembelajaran Melalui Classroom Action Research (CAR) Bagi Guru-Guru SMP-Tahfidzul Qur'an Mu'adz Bin Jabal Kendari
}

\author{
Hunaidah $^{1)} *$ Erniwati $^{1)}$, Sul Daeng Naba ${ }^{2)}$ \\ ${ }^{1)}$ Dosen Jurusan Pendidikan Fisika, Universitas Halu Oleo \\ ${ }^{2)}$ Mahasiswa Jurusan Pendidikan Fisika, Universitas Halu Oleo \\ Email: hunaidah@uho.ac.id
}

\begin{abstract}
Abstrak: Kegiatan Pengabdian ini ditujukan sebagai upaya meningkatkan kualitas pembelajaran dan profesionalisme guru-guru SMP-TQ Muadz bin Jabal Kendari dengan menggunakan kegiatan pelatihan peningkatan kemampuan melaksanakan inovasi pembelajaran melalui Classroom Action research (CAR). $C A R$ ditujukan untuk mencapai beberapa target luaran yang meliputi: 1) Meningkatkan pemahaman guruguru SMP-TQ Muadz bin Jabal Kendari mengenai konsep dan praktik CAR untuk memaksimalkan evaluasi diri sebagai bagian dari proses pengembangan kompetensi profesional guru; 2) Meningkatkan pemahaman guru mengenai konsep dan praktik CAR; 3) Mengurangi kesenjangan kualitas pembelajaran antara sekolah mitra dengan sekolah lain yang mumpuni dalam ber CAR karena adanya saling berbagi permasalahan, pertukaran ide dan pengalaman, ujicoba bersama, diskusi terbuka antara guru dan tim iptek, dan penyesuaian solusi dengan struktur institusi dan praktik kebiasaan; 4) Bagi sekolah, jika guruguru SMP-Tahfidzul Quran (SMP-TQ) Muadz Bin Jabal Kendari telah mampu melakukan Penelitian Tindakan Kelas (CAR), maka hasil belajar siswa akan meningkat sehingga diharapkan kualitas sekolah juga akan meningkat. Pada PKM kali ini dihasilkan 7 judul proposal CAR yang dihasilkan oleh guru-guru SMP-TQ Muadz Bin Jabal Kendari yang siap diajukan ketingkat Action
\end{abstract}

Kata kunci: Classroom Action Research (CAR), Inovasi Pembelajaran Profesionalisme Guru

\begin{abstract}
This Community Service activity intended as an effort to improve the quality of learning and professionalism of teacher in Junior High School Tahdizul Qur'an Muadz bin Jabal Kendari by using training activities to improve the ability to implement innovative learning through Classroom Action research (CAR). CAR is intended to achieve several output targets which include: 1) Increase the understanding of teacher in Junior High School Tahdizul Qur'an Muadz bin Jabal Kendari about CAR concepts and practices to maximize self-evaluation as part of the teacher professional competency development process; 2)Improve teacher understanding of CAR concepts and practices; 3) Reducing the teaching quality gap between schools partner with other schools that qualified in air-CAR for their share of problems, exchange ideas and experiences, trials with, frank discussion between a teacher and a team of science and technology, and adjustment of the solution to the institutional structures and informal practices; 4) For schools, if the teacher in Junior High School Tahdizul Qur'an Muadz bin Jabal Kendari can conduct Classroom Action Research (CAR), then student learning outcomes will improve so that it hoped that the quality of the school would also increase. At this time PKM produced seven titles of CAR proposals provided by the teacher in Junior High School Tahdizul Qur'an Muadz bin Jabal Kendari who were ready to be submitted to the Action level
\end{abstract}

Keywords: Classroom Action Research (CAR), Learning Innovation Professionalism of Teach

\section{PENDAHULUAN}

Pemerintah selalu melakukan usaha peningkatan mutu/kompetensi guru melalui pelatihan dan tidak sedikit dana yang dialokasikan untuk pelatihan guru (Aziz, 2015; Puspita, 2009). Sayangnya usaha dari pemertintah ini kurang memberikan dampak yang signifikan terhadap peningkatan mutu guru (Riyati, 2007). Minimal ada dua hal yang menyebabkan pelatihan guru belum berdampak pada peningkatan mutu pendidikan. Pertama, pelatihan tidak berbasis pada permasalahan nyata di dalam kelas (Fitria et al. 2019). Materi pelatihan yang sama disampaikan kepada semua guru tanpa mengenal daerah asal. Padahal kondisi sekolah di suatu daerah belum tentu sama dengan sekolah di daerah lain. Kedua, hasil pelatihan hanya menjadi pengetahuan saja, tidak diterapkan pada pembelajaran di kelas atau 
kalaupun diterapkan hanya sekali, dua kali saja dan selanjutnya kembali "seperti dulu lagi" back to basic (Widyoko, 2009).

Kompetensi guru bukan merupakan sesuatu yang sifatnya statis, melainkan dinamis sesuai dengan perkembangan ilmu pengetahuan dan teknologi (Mahrdika et al. 2019). Hal ini sejalan dengan tuntukan terhadap guru untuk selalu berpikir kreatif dan inovatif dalam mengembangkan pembelajaran yang dikelolanya (Suryadi, 2007; Hunaidah et al. 2018). Berdasarkan infornasi dari guru IPA SMP-TQ Muadz Bin Jabal Kendari bahwa mereka sangat membutuhkan pembimbingan dalam rangka memperbaiki peroses pembelajaran dalam usaha memperbaiki hasil pembelajaran. Salah satu usaha yang bisa dilakukan adalah meningkatkan kemampuan guru dalam melakukan inovasi pembelajaran. Hal ini tidak mudah dilakukan oleh guru tanpa bimbingan dari pihak yang berkompoten untuk membantu menyelesaikan permasalahn tersebut. Dengan demikian perlu dicarikan solusi dengan memberikan pelatihan agar para guru dapat memotivasi guru-guru SMP melakukan inovasi pembelajaran sekaligus melakukan penenlitian dan membuat karya tulis (KTI) sehingga dapat digunakan sebagai syarat untuk menduduki pangkat/golongan ruang kejenjang selanjutnya.

Salah satu upaya yang dapat dilakukan membantu guru dalam melaksanakan Penelitian Tindakan Kelas (CAR) melalui program pengabdian kepada masyarakat yang dikembangkan oleh Lembaga Pengabdian Kepada Masyarakat (LPPM) Universitas Halu Oleo Kendari, dapat membantu guru-guru SMP melaksanakan CAR, mulai dari membantu perencanaan, pelaksanaan tindakan dan membuat laporan yang memenuhi syarat suatu karya tulis ilmiah.

Pelaksanaan CAR memiliki keuntungan /kemudahan bagi guru sebagai beikut: (1) sambil melaksanakan pembelajaran, guru sekaligus dapat melakukan kegiatan penelitian, (2) metode pengumpulan data yang digunakan tidak menuntut waktu yang banyak dari guru sehingga berpeluang tidak menggangu proses pembelajaran, (3) metodologi yang digunakan cukup reliabel, tidak menuntuk menggunakan penghitungan statistik yang rumit dalam pengolahan data dan, (4) masalah penelitian yang di teliti merupakan masalah yang ditemukan/dialami sendiri oleh guru di dalam kelas (Mulyasa, 2010; Jana \& Pamungkas, 2018; Kawuri \& Fayanto, 2019).

Bedasarkan solusi yang telah disepakati untuk mengatasi permasalahan, maka guru-guru menerima bimbingan dari dosen tentang bagaimana menyusun kerangka dalam melakukan perbaikan pembelajaran berdasarkan langkahlangkah dari setiap tahapan CAR dari tahap perencanaan (skenario pembelajaran, instrumen, media), melaksanakan dana melakukan observasievaluasi dalam ruang kelas

\section{METODE}

Metode yang digunakan meliputi pemaparan materi CAR secara ringkas, kemudian diikuti dengan diskusi, tanya jawab, dan pemberian tugas mandiri kepada setiap peserta untuk melaksanakan CAR dalam proses pembelajaran yang dikelolanya.

Adapun rincian kegiatan dalam pelatihan ini dapat diuraikan sebagai berikut:

\section{a. Pemilihan peserta}

Pemilihan peserta dilakukan dengan berkoordinasi dengan Dinas Diknas Kabupaten Buton untuk memperoleh data guru-guru SMP-TQ Muadz bin Jabal Kendari. Selanjutnya mengambil sampel guru SMP-TQ Muadz bin Jabal Kendari dari setiap guru mata pelajaran. Jumlah peserta pelatihan adalah 20 orang guru yang disesuaikan dengan jumlah dana yang disiapkan BLU UHO tahun 2018.

\section{b. Workshop}

Setelah pemilihan peserta dilakukan, maka selanjutnya ketua pengusul mengundang guru-guru untuk mengikuti workshop selama satu hari dengan kegiatan berupa.

1. Pemberian model cara penyusunan usulan CAR yang menyajikan bagaimana mengungkap masalah CAR, mencari akar permasalahan dan menentukan cara pemecahannya serta metode/prosedur pelaksanaannya;

2. Penyampaian materi teknik penulisan karya tulis dan artikel ilmiah yang akan diterbitkan dalam suatu majalah ilmiah;

3. Pembimbing kelompok peserta oleh masingmasing dosen pembimbing.

\section{HASIL PENELITIAN}

Kegiatan pengabdian ini diikuti oleh 20 orang guru yang berasal dari SMP-TQ Muadz Bin Jabal Kendari. Pada pelaksanaan kegiatan pengabdian, terlebih dahulu guru diberikan pengantar materi tentang Classrom Action Research. 


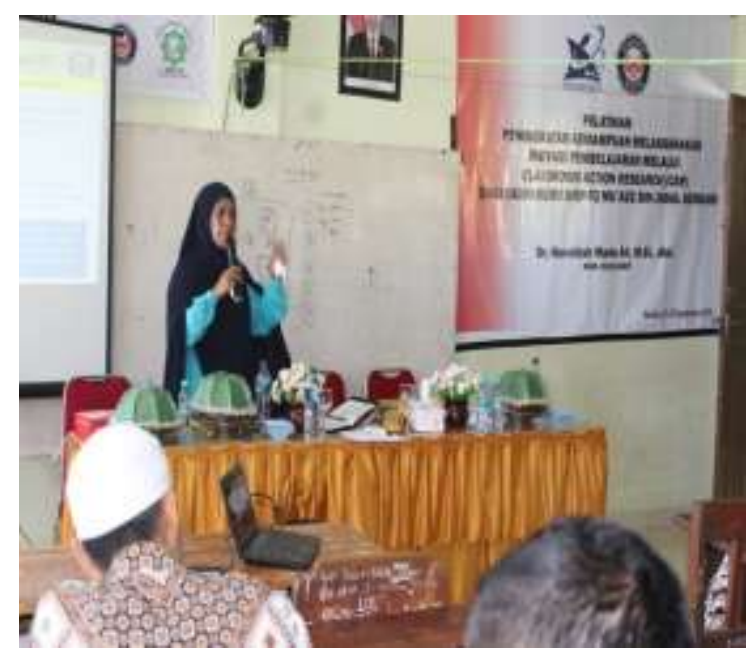

Gambar 1. Ketua Tim Penyampaian Materi

Setelah kegiatan penyampaian materi selesai, maka selanjutnya guru didampingi oleh tim pengabdian.

Pendampingan berfokus pada tanya jawab tahap pelaksanaan $C A R$.

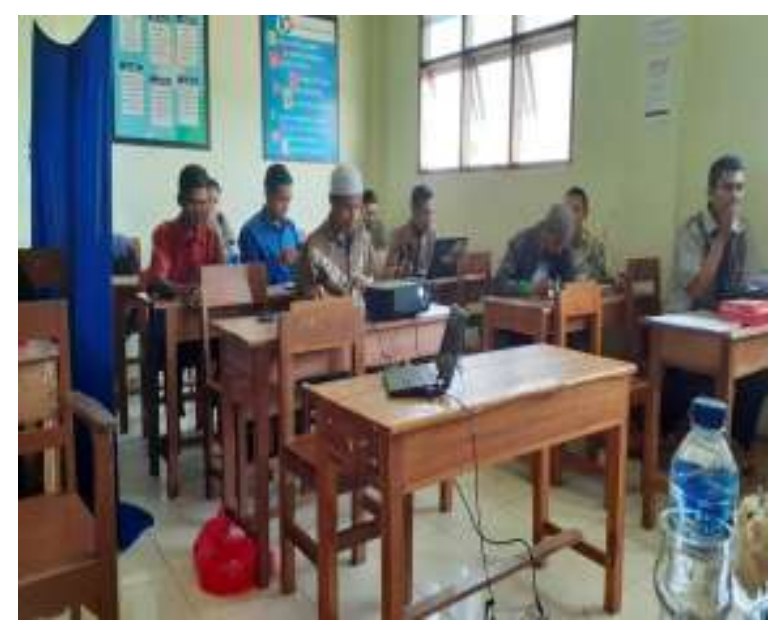

Gambar 2. Kegiatan Pendampingan

Tabel 1. Daftar Nama Kegiatan Pendampingan

\begin{tabular}{|c|c|c|}
\hline $\begin{array}{c}\text { Nama-nama Tim } \\
\text { Peneliti }\end{array}$ & Rumpun & Judul \\
\hline $\begin{array}{l}\text { Rahmawati N., S.Pd } \\
\text { Sitti Raodah Karim, S.Pd. }\end{array}$ & IPA & $\begin{array}{l}\text { Meningkatkan Motivasi dan hasil belajar Siswa Kelas 9B pada } \\
\text { materi sistem Ekskresi dengan penerapan model pembelajaran } \\
\text { kooperaif tipe Jigsaw }\end{array}$ \\
\hline $\begin{array}{l}\text { Rita Saha } \\
\text { Suhartina } \\
\text { Zulkifli, } \\
\text { Rugaya, }\end{array}$ & IPS & $\begin{array}{l}\text { Peningkatan Hasil Belajar IPS materi sejarah nasional melalui } \\
\text { penerapan model pembelajaran Problem Based learning berbasis } \\
\text { Quantum Teaching kelas 9A di SMP-TQ Muadz Bin Jabal } \\
\text { Kendari }\end{array}$ \\
\hline $\begin{array}{l}\text { Yuni mahadiyanti, S.Pd. } \\
\text { HasnawatiSahir, S.Pd } \\
\text { Verawati, S.Pd. }\end{array}$ & $\begin{array}{l}\text { Bahasa } \\
\text { Indonesia }\end{array}$ & $\begin{array}{l}\text { Meningkatkan keterampilan menulis surat resmi melalui Model } \\
\text { Pembelajaran Inquary pendekatan konstruktivisme assisted } \\
\text { learning dikelas VII SMP-TQ Muadz Bin Jabal Kendari }\end{array}$ \\
\hline
\end{tabular}




\begin{tabular}{|c|c|c|}
\hline $\begin{array}{c}\text { Nama-nama Tim } \\
\text { Peneliti }\end{array}$ & Rumpun & Judul \\
\hline $\begin{array}{l}\text { Rugaya, S.Pd. } \\
\text { Muh. Asruddin, S.Pd. }\end{array}$ & PKN & $\begin{array}{l}\text { Penerapan Model pembelajaran Discovery Learning media Audio } \\
\text { Visual untuk meningkatkan hasil belajar siswa kelas VII pada } \\
\text { konsep Mengevaluasi Dampak Globaliisasi di SMP-TQ Muadz } \\
\text { Bin Jabal Kendari }\end{array}$ \\
\hline $\begin{array}{l}\text { Abdul Madjid, S.PdI. } \\
\text { Hamida, S.Ag } \\
\text { Aswan, S.Pd. } \\
\text { Abdul Majid, S.PdI }\end{array}$ & $\begin{array}{l}\text { Pendidikan } \\
\text { Agama } \\
\text { Islam }\end{array}$ & $\begin{array}{l}\text { Implementasi Model Pembelajaran Problem Based learning } \\
\text { metode sosio drama dan bermain peran untuk meningkatkan } \\
\text { materi akhlaqul karimah mata mata pelajaran pendidikan Agama } \\
\text { Islam kelas 8D SMP-TQ Muadz Bin Jabal Kendari tahun } \\
\text { 2019/2020 }\end{array}$ \\
\hline $\begin{array}{l}\text { Muh. Asruddin, } \\
\text { Pratiwi Nusi, S } \\
\text { Syarif Hidayat, }\end{array}$ & $\mathrm{N}$ & $\begin{array}{l}\text { Peningkatan Kemampuan Berpikir Kreatif Matematika Siswa } \\
\text { Kelas 7C SMP-TQ Muadz Bin Jabal pada Topik Aritmetika } \\
\text { Sosisal Melalui Penerapan Model Pembelajaran Kooperatif } \\
\text { Teknik pemanfaatan soal open ended }\end{array}$ \\
\hline $\begin{array}{l}\text { Rabiah, S.Pd. } \\
\text { Lilis Muflihah, S.Pd. }\end{array}$ & $\begin{array}{l}\text { Bahasa } \\
\text { Inggris }\end{array}$ & $\begin{array}{l}\text { Upaya peningkatan hasil belajar Bahasa Inggris pada materi } \\
\text { descriptive text melalui Model Pembelajaran Inquiry metode } \\
\text { bermain peran pada siswa kelas 8C SMP-TQ Muadz Bin Jabal } \\
\text { Kendari }\end{array}$ \\
\hline
\end{tabular}

Penelitian tindakan kelas adalah metode untuk mencari tahu apa yang terbaik di kelas kita sendiri sehingga kita dapat meningkatkan pembelajaran siswa. Banyak guru menggunakan Penelitian tindakan kelas untuk meningkatkan pengetahuan tentang pengajaran. Banyak guru mempraktekkan refleksi pribadi tentang mengajar; yaitu, mereka melihat kembali apa yang telah berhasil dan belum bekerja di kelas dan berpikir tentang bagaimana mereka dapat mengubah strategi pengajaran mereka untuk meningkatkan pembelajaran (Mattetal, 2002). Hole \& McEntee (1999) mengemukakan beberapa langkah yang berguna untuk meningkatkan refleksi terhadap proses pembelajaran. Beberapa peneliti telah melakukan studi empiris mengenai pengajaran dan pembelajaran. Mereka melaporkan bahwa CAR (Penelitian Tindakan Kelas) sangat cocok untuk meningkatkan pembelajaran siswa. CAR lebih sistematis dan berbasis data dari pada refleksi pribadi, tetapi lebih informal dan pribadi dari pada formal penelitian pendidikan. Tujuan CAR adalah untuk meningkatkan pengajaran anda sendiri di kelas anda sendiri (sekolah Anda). Tentu hal ini sangat menunjang dalam proses pembelajaran (Kawuri et al. 2019).

Berdasarkan hasil pelaksanaan kajian terlihat bahwa masih banyak guru belum mampu mengimplemntasikan penelitian tindakan secara maksimal. Hal ini gambar dari hasil kajian bahwa guru belum mampu mendeskripsikan secara detail makna dari penelitian tindakan kelas. Terlebih banyak guru yang belum belum mampu mengambarkan proses penelitiaan tindakan kelas selama proses pembelajaran. Penelitian tindakan kelas lebih menekankan pada proses, dimana peran guru sangat penting guna mendukung siswa selama proses pembelajaran. Penelitian tidakan kelas hadir untuk membantu siswa dalam mengani permasalahan belajar yang dialami oleh seorang siswa. Oleh sebab itu, guru harus pandai-paindanya dalam memainkan peran selama proses pembelajaran. Hal ini tentu membutuhkan keahlian guru selama proses pembelajaran. Guru harus bisa memposisikan diri pada setiap fase dalam penelitian tindakan kelas. Guru harus mampu menelah keadaan atau kondisi siswa selama proses pembelajaran berlangsung. Khasinah (2013) melaporkan bahwa Guru menggunakan penelitian tindakan untuk mencari tahu apa yang berhasil di kelas dan apa yang tidak. Dengan begitu banyak strategi pengajaran yang mereka miliki, guru perlu menentukan mana yang terbaik untuk mereka dan untuk siswa mereka, daripada hanya mengikuti tren pendidikan terbaru.

Mattetal (2002) melaporkan bahwa Proses CAR mencakup tujuh langkah yang dapat dikelola. Instruktur dapat menyelesaikan proyek-proyek kecil dalam satu semester, sementara proyekproyek yang lebih ambisius mungkin memerlukan perencanaan ke depan atau mengumpulkan data selama beberapa semester. Identifikasi pertanyaan; Tinjau literatur; Rencanakan strategi penelitian Mengumpulkan data; Analisis data; Ambil 
tindakan berdasarkan hasil; Temuan. Tujuan langkah ini memainkan peran penting selama proses CAR berlangsung. Seperti yang di laporkan oleh O'connor et al. (2006) bahwa Penelitian tindakan memberikan jalan untuk pembelajaran guru. Dalam studi Johnson \& Button (2000), para guru memperhatikan secara detail hubungan antara pembelajaran mereka sendiri dan pembelajaran siswa mereka, menegaskan bahwa prinsip-prinsip pembelajaran yang baik yang mereka gunakan dengan siswa mereka sendiri diterapkan pada ruang kelas mereka sendiri. Mereka menemukan dengan menggunakan penelitian tindakan, para guru mulai menghargai kemampuan mereka sendiri untuk meningkatkan pengetahuan melalui proyek mereka sendiri. Sax \& Fisher (2001) melaporkan dalam kajianya bahwa penelitian tindakan memungkinkan guru peluang untuk mengidentifikasi perubahan yang perlu mereka buat dalam praktik mengajar mereka dengan memberi guru kerangka kerja untuk membangun proyek kelas mereka sendiri. Dalam banyak kasus, ketika guru merancang proyek penelitian tindakan mereka sendiri, mereka menggunakan pendekatan sistematis untuk memastikan jawaban atas pertanyaan atau masalah pengajaran. Jenis pengembangan profesional yang diterapkan ini sangat kuat karena bersifat berkelanjutan, interaktif, dan sistemik.

Oleh karena itu, Penelitian tindakan kelas dapat memberdayakan guru untuk berubah dengan mendorong seorang guru keluar dari zona nyamannya. Sering kali, agar pertumbuhan pribadi dan profesional terjadi, didorong keluar dari zona nyaman adalah tantangan. Tantangan-tantangan ini diperlukan, terutama terkait dengan praktik di ruang kelas, untuk mengarah pada perubahan positif. Penelitian tindakan kelas menempatkan guru dalam peran baru, guru sebagai peneliti, guru sebagai pengambil keputusan (Mertler, 2006) dan guru sebagai agen perubahan. Melaksanakan proses penelitian tindakan telah membantu menginformasikan instruksi harian, dan telah mengubah, berubah, dan diperluas kurikulum perspektif, pilihan, dan berpikir guru

\section{KESIMPULAN}

Pelatihan dalam meningkatkan kemampuan melakukan inovasi pembelajaran melalui Classrom Action Research pada guru-guru SMPTQ Muadz Bin Jabal Kendari telah berhasil (1) Mengembangkan pengetahuan guru SMP-TQ
Muadz Bin Jabal Kendari tentang model-model pembelajaran yang dapat digunakan untuk meningkatkan kompetensi guru; (2) Mengembangkan pengetahuan dan meningkatkan keterampilan mengajar inovatif para guru SMP-TQ Muadz Bin Jabal Kendari; (3) Mengembangkan pengetahuan dan keterampilan dalam bentuk penyusunan proposal $C A R$, dan meningkatkan keterampilan melakukan $C A R$ para guru SMP-TQ Muadz Bin Jabal Kendari; (4) Menjalin hubungan kerja sama antara tim PKM UHO dengan para guru SMP-TQ Muadz Bin Jabal Kendari.

\section{SARAN}

Diharapkan kepada pihak sekolah atau LPPM UHO dapat memfasilitasi kami untuk melanjutkan mendampingi para guru SMP-TQ Muadz Bin Jabal Kendari dalam melanjutkan proposalnya pada tahap action. Demikian pula pendampingan pada saat buat laporan dan penyusunan artikel yang siap diterbitkan oleh jurnal yang relevan

\section{DAFTAR PUSTAKA}

Aziz, A. (2015). Peningkatan mutu pendidikan. Jurnal Studi Islam, 10(2), 1-13.

Fitria, H., Kristiawan, M., \& Rahmat, N. (2019). Upaya Meningkatkan Kompetensi Guru Melalui Pelatihan Penelitian Tindakan, Jurnal Pengabdian Masyarakat UNWAHAS, 4(1), 14-24

Hunaidah, M., Armin, A., \& Fayanto, S. (2018, May). Penerapan model pembelajaran PredictObserve-Explain (POE) dengan metode demonstrasi untuk meningkatkan aktivitas dan hasil belajar IPA Fisika materi pokok kalor Kelas VII2 SMP Negeri 15 Kendari. In Quantum: Seminar Nasional Fisika, dan Pendidikan Fisika (pp. 293-298).

Hole, S. and McEntee, G.H. (1999). Reflection is at the heart of practice. Educational Leadership 56(8), 34-37

Jana, P., \& Pamungkas, B. (2018). Pelatihan penelitian tindakan kelas bagi guru SD Negeri Guwosari. Abdimas Dewantara, 1(1), 39-46.

Johnson, M., \& Button, K. (2000). Connecting graduate education in language arts with teaching contexts: The power of action research. English Education, 32, 107-126. 
Kawuri, M. Y. R. T., Ishafit, I., \& Fayanto, S. (2019). Efforts to improve the learning activity and learning outcomes of physics students with using a problem-based learning model. IJIS Edu: Indonesian Journal of Integrated Science Education, 1(2), 105-114.

Kawuri, M. Y. R. T., \& Fayanto, S. (2020). Penerapan Model Discovery Learning Terhadap Keaktifan dan Hasil Belajar Siswa Kelas $\mathrm{X}$ MIPA SMAN 1 Piyungan Yogyakarta. Jurnal Penelitian Pendidikan Fisika, 5(1), 1-8.

Khasinah, S. (2013). Classroom action research. PIONIR: Jurnal Pendidikan, 4(1).

Mahardika, A. I., Arifuddin, M., Salam, A., \& Sari, D. P. (2019). Efektivitas workshop penelitian tindakan kelas untuk meningkatkan pemahaman penelitian guru di Kabupaten Balangan, Kalimantan Selatan. Abdimas Toddopuli: Jurnal Pengabdian Pada Masyarakat, 1(1), 56-62.

Mettetal, G. (2002). The what, why and how of classroom action research. Journal of the Scholarship of Teaching and Learning, 6-13.

Mettetal, G. (2002). Improving teaching through classroom action research. Essays on teaching excellence: Toward the best in the Academy, 14(7).
Mertler, C, A. (2006). Action research: Teachers as researchers in the classroom. Thousand Oaks, CA: Sage

Mulyasa, E. (2010). Penelitian tindakan kelas. Bandung: PT Remaja Rosdakarya.

O'Connor, K. A., Greene, H. C., \& Anderson, P. J. (2006). Action Research: A Tool for Improving Teacher Quality and Classroom Practice. Online Submission.

Puspita, E. (2009). Upaya Meningkatkan Kemampuan Guru Matematika Melakukan Penelitian Tindakan Kelas (PTK) Melalui Kegiatan Lesson Study. In Artikel Seminar Nasional, Jurusan Pendidikan Matematika FPMIPA UPI.

Riyati, S. (2007). Sistem Pembinaan Profesional Guru Pendidikan IPA Melalui Lesson Study. Bandung: Jurusan Pendidikan Biologi FPMIPA Universitas Pendidikan Indonesia.

Sax, C., \& Fisher, D. (2001) Using qualitative action research to effect change: Implications for professional education. Teacher Education Quarterly, 28 (2), 71-80.

Suryadi, A. (2007). Pemanfaatan ICT dalam pembelajaran. Jurnal Pendidikan Terbuka dan Jarak Jauh, 8(2), 83-98.

Widoyoko, E. P. (2009). Evaluasi program pembelajaran. Yogyakarta: Pustaka pelajar. 